Check for updates

Montreal

Cite this as: BMJ 2021;375:n2659 http://dx.doi.org/10.1136/bmi.n2659 Published: 01 November 2021

\title{
Covid-19: FDA puts Moderna's paediatric application on hold to investigate side effects
}

\section{Owen Dyer}

The US emergency use authorisation of Moderna's coronavirus vaccine in people aged 12-17 will be delayed, the company has been told by the Food and Drug Administration (FDA), while the regulator reviews new international data suggesting that the risk of myocarditis and pericarditis, the most problematic side effect of mRNA vaccines, may be higher after vaccination with Moderna's product than with its Pfizer competitor.

Moderna said it will also delay its application for authorisation in 6-11 year olds. The FDA warned the company that the authorisation in 12-17 year olds could now take until January, Moderna said in a statement.

A possible increase in the rate of myocarditis and pericarditis, which involve inflammation of the muscle tissue around the heart, has been observed in several countries among people who recently received an mRNA vaccine such as Pfizer or Moderna. The risk appears to be heavily concentrated among the young, especially males, and is highest after the second dose. No deaths have been reported.

The US data are inconsistent on the question of a higher rate with Moderna's vaccine,${ }^{1}$ but European adverse event reporting systems have picked up such a signal. After reviewing European data, the European Medicines Agency decided that an update to the warning label was sufficient for both Pfizer and Moderna's vaccines. The UK approved Moderna's vaccine for those aged 12-17 in August, but generally only recommends one dose in the absence of covid risk factors.

The first hints of a delay in the FDA's paediatric authorisation of Moderna came in August, when Canada reported seeing myocarditis and pericarditis two and a half times more frequently among those who received the Moderna vaccine than in those who had received Pfizer's. Canada's regulator is still reviewing its data, but for now has settled for updating the labelling of both mRNA vaccines, concluding that the risk-benefit equation remains heavily in favour of vaccination.

The FDA reviewed those data and reached a similar conclusion, but then learnt of new data from Scandinavian countries again suggesting a higher rate of these side effects with Moderna's vaccine. Finland and Sweden have since recommended against the use of Moderna in men younger than $30 .^{2}$ It is the FDA's analysis of this unpublished Scandinavian data that is causing the delay in Moderna's paediatric authorisation.

The same reporting systems that show a higher rate of side effects from Moderna's vaccine are also frequently showing slightly better protection against covid than from Pfizer's vaccine. The two vaccines use very similar mRNA technology, but while Pfizer's adult dose carries $30 \mu \mathrm{g}$ of mRNA, Moderna's adult dose delivers 10oug of mRNA. Both vaccines use the full adult dose in adolescents aged over 12.

In younger children, both used reduced doses, but Pfizer's is reduced more, to $10 \mu \mathrm{g}$ of mRNA in children 5-11, compared with 50 19 of mRNA in Moderna's dose for 6-12 year olds. Hence Moderna's paediatric dose contains more mRNA than Pfizer's adult dose.

Canada's National Advisory Committee on Immunization suggested that provinces holding adequate stocks of both mRNA vaccines might choose to use the Pfizer on their younger recipients and save the Moderna for adults. ${ }^{3}$

Such an approach would not slow the pace of vaccination in the US, where the mass immunisation of children 5-11 with the Pfizer shot is expected to begin this week. But the delay in authorising Moderna might influence public confidence-uptake of the Johnson \& Johnson vaccine never recovered in the US after the Centers for Disease Control paused its administration over concerns about thrombocytopenia.

Moderna said in a statement that "to date, the observed rate of myocarditis reports in those less than 18 years of age in Moderna's global safety database does not suggest an increased risk of myocarditis in this population.” But, the company added, it "does not yet have access to data from some recent international analyses.”

Su JR. Myopericarditis following covid-19 vaccination: updates from the vaccine adverse event reporting system. CDC Vaccination Planning Meeting 30 August 2021. www.cdc.gov/vaccines/acip/meetings/downloads/slides2021-08-30/03-COVID-Su-508.pdf.

2 Paterlini M. Covid-19: Sweden, Norway, and Finland suspend use of Moderna vaccine in young people "as a precaution”. BMJ2021;375:n2477. doi: 10.1136/bmj.n2477 pmid: 34635488

3 Summary of National Advisory Committee on Immunization (NACl) statement: recommendation on the use of mRNA covid-19 vaccines in adolescents 12 to 17 years of age. National Advisory Committee on Immunization. 27 August 2021. www.canada.ca/en/public-health/services/immunization/national-advisory-committee-on-immunization-naci/recommendations-use-covid-19-vaccines/mrna-adolescents/summary.html.

This article is made freely available for use in accordance with BMJ's website terms and conditions for the duration of the covid-19 pandemic or until otherwise determined by BMJ. You may use, download and print the article for any lawful, non-commercial purpose (including text and data mining) provided that all copyright notices and trade marks are retained. 